\title{
Efforts to Improve Understanding of Science Concepts Through Audio-Visual Media for Elementary School Students
}

\author{
Umi Istinganah \\ SD Negeri Kedungmulyo \\ ispeyek@gmail.com
}

\section{Article History}

accepted $14 / 11 / 2020$

approved 21/11/2020

published 26/11/2020

\begin{abstract}
The purpose of this research is to improve understanding of the concept of Natural Science (IPA) in the material of the Food Digestive System in Humans. This research is a classroom action research (PTK) which is conducted in two cycles, each cycle consisting of planning, implementation, observation, and reflection stages. The subjects of this study were 17 students of class V SD Negeri Kedungmulyo for the 2020/2021 academic year. Data collection techniques using test and non-test techniques. The assessment instrument uses item items and observations of the scoring rubric. Analysis of the data used in the study included a comparative descriptive technique, namely a statistical technique by comparing the scores between cycles, the mean, the minimum score, the maximum, and the percentage. The results of the study that the use of audio-visual media can improve student learning outcomes in science subject content on the food digestive system material. The conclusion of this study is that using audio visual media can improve understanding of the concept of science in the material of the digestive system in humans in fifth grade students of SD Negeri Kedungmulyo.
\end{abstract}

Keywords: Concept Understanding, Audio Visual, Science

\section{Abstrak}

Tujuan penelitian ini adalah meningkatkan pemahaman konsep IImu Pengetahuan Alam (IPA) pada materi Sistem Pencernaan Makanan pada Manusia. Penelitian ini merupakan penelitian tindakan kelas (PTK) yang dilaksanakan dalam dua siklus, setiap siklus terdiri dari tahap perencanaan, pelaksanaan, observasi, dan refleksi. Subjek penelitian ini adalah peserta didik kelas V SD Negeri Kedungmulyo tahun pelajaran 2020/2021 yang berjumlah 17 peserta didik. Teknik pengumpulan data dengan teknik tes dan non tes. Adapun instrumen penilaiannya menggunakan butir-butir soal dan pengamatan rubrik penilaian. Analisa data yang digunakan dalam penelitian meliputi yaitu teknik deskriptif komparatif yakni teknik statistik dengan membandingkan skor antar siklus, mean, skor minimal, maksimal, dan persentase. Hasil penelitian bahwa Penggunaan media audio visual dapat meningkatkan hasil belajar siswa pada muatan pelajaran IPA pada materi sistem pencernaan makanan pada manusia. Kesimpulan dari penelitian ini adalah menggunakan media audio visual dapat meningkatkan pemahaman konsep IPA pada materi sistem pencernaan makanan pada manusia pada siswa kelas V SD Negeri Kedungmulyo.

Kata kunci: Pemahaman Konsep, Audio Visual, IPA

Social, Humanities, and Education Studies (SHEs): Conference Series https://jurnal.uns.ac.id/shes

p-ISSN 2620-9284

e-ISSN 2620-9292 


\section{PENDAHULUAN}

Pendidikan merupakan hal yang terpenting dalam kehidupan manusia untuk menjadi lebih baik, salah satu permasalahan yang dihadapi pendidikan di Indonesia adalah rendahnya mutu pendidikan dari setiap jenjang dan satuan pendidikan. Berbagai upaya untuk meningkatkan mutu pendidikan nasional terus menerus dilakukan baik oleh pemerintah maupun masyarakat, misalnya pengembangan kurikulum nasional dan lokal, meningkatkan kompetensi guru, pengadaan media pembelajaran seperti buku dan alat pembelajaran, pengadaan dan perbaikan sarana dan prasarana di sekolah, hal tersebut dilakukan untuk meningkatkan mutu pendidikan di Negara ini

Proses pembelajaran tematik IPA di sekolah dasar dilaksanakan tergantung pada kondisi sekolahnya. IPA merupakan muatan pelajaran yang mempelajari peristiwaperistiwa yang terjadi di alam. Secara umum pengajaran Ilmu Pengetahuan Alam (IPA) masih menggunakan paradigma yang lama dalam proses belajar dimana guru mengajarkan dengan metode konversional yaitu ceramah dan mengharapkan peserta didik duduk, diam, dengar, catat dan hafal $(3 \mathrm{DCH})$ namun perlu diketahui hanya sedikit yang menggunakan metode demontrasi sehingga Kegian Belajar Mengajar (KBM) Menjadi monoton dan kurang menarik perhatian peserta didik.

Pada umumnya masalah yang di hadapi di sekolah dasar dalam pembelajaran IPA adalah berkaitan dengan kurangnya penggunaan media dan model-model pembelajaran yang inovatif yang dilakukan oleh guru dalam pembalajaran di kelas, kurangnya buku sumber, dan adanya guru yang berperan sengat dominan dalam kegiatan pembalajaran (Teacher Center) sehingga peserta didik tidak diberikan kersempatan untuk terlibat dalam kegiatan pembelajaran dan penggunaan media pembelajaran yang belum sepenuhnya dilakukan dalam proses pembelajaran. Berdasarkan kondisi tersebut dirasakan perlunya penggunaan media dan model pembelajaran yang dapat membantu peserta didik untuk memahami proses pembelajaran IPA dan meningkatkan hasil belajarnya, untuk itu perlu adanya upaya perbaikan pembelajaran agar lebih menarik dan mendorong peserta didik untuk belajar, salah satu alternative pembelajaran adalah dengan menggunakan media pembelajaran audio visual menggunakan Power point pada pembelajaran IPA khususnya tentang sitem pencernaan makanan pada manusia di kelas V SD agar dapat meningkatkan pemahaman konsep peserta didik dalam pembelajaran IPA, dan dapat memperoleh hasil yang maksimal dalam proses belajar.

Media pembelajaran dalam mengajar memengang peranan penting sebagai atau alat bantu untuk menciptakan proses belajar pengajaran IPA, keberadaan media pembelajaran jelas mempunyai pengaruh terhadap keberhasilan belajar mengajar yang efektif (Nana Sudjana, 2002 : 99). Dalam keitannya dengan pengajaran IPA keberadaan media pembelajaran jelas mempunyai pengaruh terhadap keberhasilan belajar mengajar. Pengajaran pada dasarnya (Nana Sudjana, 2002 : 43), adalah suatu proses terjadinya interaksi guru dan siswa melalui kegiatan terpadu dari dua bentuk kegiatan, yaitu kegitan belajar siswa dan kegiatan mengajar guru.Berdasarkan latar belakang di atas maka penulis mengambil judul mengenai "Upaya Peningkatan Pemahaman Konsep Sistem Pencernaan Makanan Pada Manusia Melalui Media Audio Visual Pada Siswa Kelas V SD Negeri Kedungmulyo".

Teori dan Penelitian Relevan

a. Penelitian Tindakan Kelas

Menurut Carr dan Kemmis (dalam IGAK Wardhani dan Kusuma Wihardit,2019: 1.3) Penelitian tindakan kelas merupakan penelitian dibidang sosial, yang menggunakan refleksi diri sebagai metode utama, dilakukan oleh orang yang terlibat didalamnya, serta bertujuan untuk melakukan perbaikan dalam berbagai aspek. Penelitian tindakan kelas (PTK adalah penelitian yang dilakukan oleh guru di kelasnya sendiri melalui refleksi diri dengan tujuan untuk memperbaiki kinerjanya sehingga 
hasil belajar siswa meningkat ( IGAK Wardhani dan Kusuma Wihardit, 2019: 1.17). Berdasarkan pendapat di atas dapat disimpulkan bahwa penelitian tindakan kelas adalah penelitian yang dilakukan oleh guru didalam kelasnya sendiri melalaui refleksi diri dengan tujuan untuk meningkatkan kemantapan kinerjanya dalam melaksanakan tugas, sehingga hasil belajar lebih meningkat.

b. Pemahaman Konsep

Berdasarkan domain kognitif Bloom, mengemukakan pemahaman konsep merupakan tingkatan kedua. Pemahaman konsep didefinisikan sebagai kemampuan untuk menyerap arti dari materi atau bahan yang dipelajari. Bloom, (Vestari 2009:23), Aspek pemahaman merupakan aspek yang mengacu pada kemampuan untuk mengerti, memahami dan memaknai arti suatu materi. Pemahaman Konsep adalah kemampuan menangkap pengertian-pengertian seperti mampu mengungkapkan suatu materi yang disajikan kedalam bentuk yang lebih dipahami, mampu memberikan interprensi dan mampu mengaplikasikannya Bloom (Dadang. S, 2009 : 31), Noval dan Gowin (Vestari, 2009 : 16), menyatakan bahwa pemahaman dapat juga dievakuasi melalui gambar dapat mengetahui yang telah dimiliki peserta didik untuk mengaitkan informasi baru dengan informasi yang telah ada dalam struktur kognitif peserta didik.

c. IPA

IPA adalah ilmu pengetahuan alam. Dalam "Encyiclopedia Britanica" disebutkan, bahwa IPA atau "natural science" adalah pengetahuan yang tersusun tentang gejalagejala alam dan hubungan sebab-akibatnya antara gejala yang satu dengan yang lainnya. Ilmu Pengatahuan Alam (IPA) berhubungan dengan cara mencari tahu tentang alam secara sistematis. Sehingga IPA bukan hanya penguasaan kumpulan pengetahuan yang berupa fakta-fakta, konsep-konsep, atau prinsip-prinsip saja tetapi juga merupakan suatu proses penemuan. Pendidikan IPA diharapkan menjadi wahana bagi peserta didik untuk mempelajari diri sendiri dan alam sekitar, serta proses pengembangan lebih lanjut dalam penerapannya didalam kehidupan sehari-hari. Proses pembelajaranya menekankan pemberian pengalaman langsung untuk mengembangkan kopetensi agar menjelajahi dan memahami alam sekitar secara ilmiah. Pendidikan IPA diarahkan untuk pelatihan berfikirmelalui pertanyaanpertanyaan. Siswa dilatih berfikir untuk merumuskan dan menyelasaikan masalah (Inquiri), Sehingga dapat membantu peserta didik untuk memperoleh pemahaman yang lebih mendalam tentang alam sekitar. IPA diperlukan dalam kehidupan seharihari untuk memenuhi kebutuhan manusia melalui pemecahan masalah-masalah yang dapat diidentifikasikan. Penerapan IPA perlu dilakukan secara bijaksana agar tidak berdampak buruk terhadap lingkungan.

d. Media Pembelajaran Audio Visual

Media berasal dari bahasa latin merupakan bentuk jamak dari "Medium" yang secara harfiah berarti "Perantara" atau "Pengantar" yaitu perantara atau pengantar sumber pesan dengan penerima pesan. Beberapa ahli memberikan definisi tentang media pembelajaran. Pengertian dari media pembelajaran adalah segala sesuatu yang dapat menyampaikan dan menyalurkan pesan dari sumber secara terencana sehingga tercipta lingkungan belajar yang kondusif diman penerimanya dapat melakukan proses belajar secara efisien dan efektif (Yudi Munadhi, 2002 : 7-8).

Menurut Sanjaya (2005: 173), media audio visual yaitu media yang selain mengandung unsur suara juga mengandung unsur gambar yang bisa dilihat, misalnya rekaman video, berbagai ukuran film, slide suara, dan lain sebagainya. Media audiovisual adalah media yang memiliki unsur suara dan juga unsur gambar. Jenis media ini memiliki keahlian yang lebih baik, sebab meliputi kedua jenis media auditif (mendengar) dan juga visual (melihat). Media Audiovisual adalah suatu alat bantu audiovisual yang berarti bahan atau alat yang dipakai dalam situasi belajar untuk membantu tulisan dan juga kata yang diucapkan dalam memberi pengetahuan, sikap, dan ide. 


\section{Rumusan Masalah}

Berdasarkan latar belakang yang telah di kembangkan di atas, maka rumusan masalah dari penelitian ini adalah :

1) Apakah dengan menerapkan pembelajaran menggunakan media audio visual dapat meningkatkan pemahaman konsep belajar IPA mengenai sistem pencernaan makanan pada manusia?

2) Bagaimana hasil dari evaluasi yang sudah dilakukan dalam meningkatkan pemahaman kosep belajar siswa dalam pembelajaran IPA melalui media pembelajaran audio visual mengenai sistem pencernaan makanan pada manusia?

Tujuan Penelitian

a. Tujuan secara umum

"Untuk mengetahui pemahaman konsep dalam pembelajaran IPA melalui media pembelajaran audio visual menganai materi sistem pencernaan makanan pada manusia".

b. Tujuan secara khusus

Untuk mengetahui pemahaman siswa dengan media pembelajaran audio visual meningkatkan pemahaman konsep belajar IPA mengenai sistem pencernaan makanan pada manusia.

Untuk mengetahui hasil dari evaluasi yang sudah dilakukan dalam meningkatkan pemahaman kosep belajar siswa dalam pembelajaran IPA melalui media pembelajaran audio visual mengenai sistem pencernaan makanan pada manusia.

\section{METODE}

Penelitian Tindakan Kelas (PTK) yang digunakan peneliti adalah jenis PTK kolaboratif. PTK kolaboratif yaitu kerja sama antara peneliti dengan teman sejawat, ide berasal dari peneliti dan yang melakukan tindakan adalah guru kelas V SD Negeri Kedungmulyo di lakukan pada semester I. Unit penelitian adalah kelas V SD Negeri Kedungmulyo.

Penelitian ini dilaksanakan pada semester I tahun pelajaran 2020/2021. Subjek dalam penelitian ini adalah siswa kelas V SD N Kedungmulyo Kecamatan Butuh Kabupaten Purworejo Jawa Tengah dengan jumlah siswa 17 anak.

Teknik pengumpulan data yang dipakai dalam penelitian tindakan ini adalah teknik tes dan non tes yang terdiri dari:

Tes berbentuk pilihan ganda, digunakan untuk mengukur kemampuan siswa setelah menggunakan media audio visual.

Non tes dalam penelitian ini berupa pengamatan implementasi RPP, pengamatan aktivitas siswa dan penilaian proses.

Pengamatan implementasi RPP digunakan untuk mendapat data tentang pengajaran guru didalam kelas serta pengamatan keaktifan siswa, sehingga bisa dilihat di dalam pelaksanaan pembelajaran benar-benar sesuai dengan kondisi dan proses yang diharapkan.

Pengamatan melalui diskusi dan presentasi dilakukan terhadap proses pembelajaran dengan menggunakan media audio visual.

Dokumentasi digunakan untuk mendapatkan data tentang identitas dari siswa. Dalam hal ini data yang diperoleh adalah daftar siswa menonjol baik dari segi positif maupun negatifnya.

Teknik analis data yang peneliti gunakan dalam penelitian untuk mengetahui tingkat pemahaman konsep sistem pencernaan makanan pada manusia menggunakan media audio visual yakni teknik statistik dengan membandingkan skor antar siklus, persentase, mean, skor minimal, maksimal. 
Siklus I

\section{HASIL DAN PEMBAHASAN}

Penelitian yang telah dilakukan akhirnya diperoleh data-data yang dapat diuraikan sebagai berikut:

a. Perencanaan Penelitian

Kegiatan yang dilakukan dalam tahapan ini adalah menyiapkan segala sesuatu yang diperlukan dalam melaksanakan skenario pembelajaran siklus I yang telah direncanakan. Kegiatan yang dilakukan antara lain:

1) Membuat Rencana Pelaksanaan Pembelajaran (RPP) dengan materi Tematik Tema 3 Makanan Sehat

2) Menyiapkan lembar observasi (pengamatan) sebagai pedoman atas proses pembelajaran menggunakan media audio visual.

3) Menyusun soal tes untuk menilai peningkatan hasil belajar siswa terhadap materi yang diajarkan.

b. Pelaksanaan Tindakan

Dilaksanakan pada tanggal 2 Nopember 2020.

Deskripsi pelaksanaan tindakan pembelajaran adalah sebagai berikut :

Kegiatan pembelajaran sesuai dengan langka- langkah pembelajaran yang ada di RPP yang telah dibuat. Pembelajaran menggunakan plafform google meet.

Pada evaluasi siklus I diikuti oleh semua peserta didik kelas V, yakni sebanyak 17 peserta didik. Peserta didik diberi waktu 30 menit untuk mengerjakan soal evaluasi melalui google form yang linknya dikirim melalui WAG.

c. Observasi

Hasil observasi yang dilakukan oleh observer selama jalannya kegiatan pembelajaran dan mengamati hasil evaluasi pada akhir kegiatan siklus pertama belum berhasil karena siswa yang tuntas hanya 5 siswa dari 17 siswa. Siswa yang sudah tuntas baru mencapai $29 \%$.

d. Refleksi

Hasil belajar pada siklus I mengalami peningkatan dibandingkan dengan keadaan awal yang disajikan pada latar belakang masalah. Hasil tes awal siswa yang tuntas mencapai $20 \%$, sedangkan pada hasil evaluasi siklus I siswa yang tuntas mencapai $29 \%$. Hal ini menunjukkan ada peningkatan hasil belajar siswa sebesar $9 \%$.

Dari deskripsi di atas menunjukkan bahwa hasil rata-rata kelas meningkat pada siklus I, namun belum dikatakan berhasil dalam pembelajaran sistem pencernaan makanan pada manusia karena siswa yang tuntas (KKM) belum mencapai $75 \%$. Berdasarkan hal tersebut, maka masih diperlukan perbaikan pembelajaran dengan media yang sama pada Siklus II. Berdasarkan hasil tes awal dan evaluasi siklus 1 tersebut, dapat dilihat presentase ketuntasan belajar siklus 1 sebagai berikut :

Tabel 1. Persentase Ketuntasan Belajar Siklus I

\begin{tabular}{|c|c|c|c|c|c|}
\hline \multirow[b]{2}{*}{ No } & \multirow[b]{2}{*}{ Uraian } & \multicolumn{2}{|c|}{ Siswa yang Tuntas } & \multicolumn{2}{|c|}{ Siswa Belum Tuntas } \\
\hline & & Frekuensi & Persentase & Frekuensi & Persentase \\
\hline 1 & $\begin{array}{lll}\text { Kondisi Awal } & \text { (sesuai dengan } \\
\text { keadaan } & \text { pada } & \text { latar } \\
\text { belakang) } & & \end{array}$ & 3 & $20 \%$ & 14 & $80 \%$ \\
\hline 2 & Siklus I & 5 & $29 \%$ & 12 & $71 \%$ \\
\hline
\end{tabular}



berikut :

Tabel di atas dapat dijelaskan siswa yang belum tuntas belajar adalah sebagai 1. Pada kondisi awal sesuai dengan latar belakang penelitian, siswa yang belum tuntas sebanyak 14 siswa dari 17 siswa atau $80 \%$.

2. Pada siklus 1 , siswa yang belum tuntas sebanyak 12 siswa dari 17 siswa atau $71 \%$. Sedangkan siswa yang tuntas belajar adalah sebagai berikut :

1. Pada kondisi awal sesuai dengan latar belakang penelitian, siswa yang tuntas sebanyak 3 siswa dari 17 siswa atau $20 \%$.

2. Pada siklus 1 , siswa yang tuntas sebanyak 5 siswa dari 17 siswa atau $29 \%$.

Berdasarkan tabel diatas dapat dibuat diagram batang hasil belajar siklus 1 sebagai berikut :

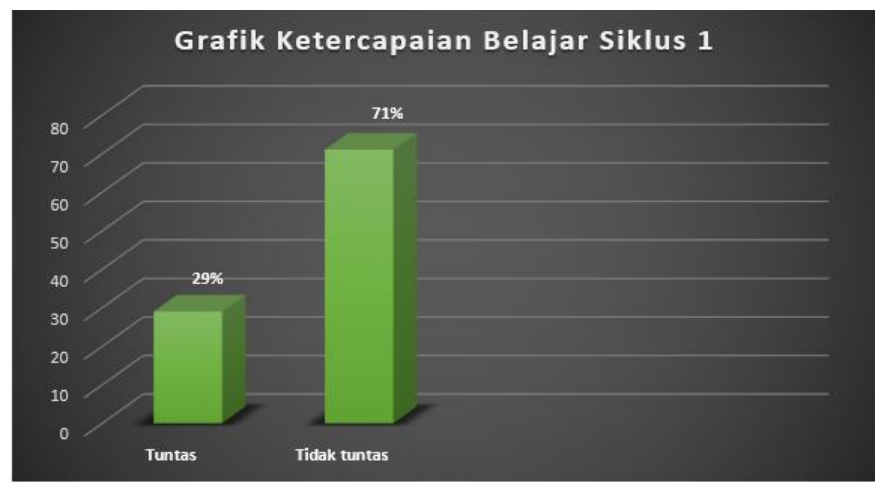

\section{Gambar 1. Grafik ketercapaian hasil belajar siklus I}

Siklus II

Penelitian yang telah dilakukan akhirnya diperoleh data-data yang dapat diuraikan sebagai berikut:

a. Perencanaan Penelitian

Kegiatan yang dilakukan dalam tahapan ini adalah menyiapkan segala sesuatu yang diperlukan dalam melaksanakan skenario pembelajaran siklus II yang telah direncanakan. Kegiatan yang dilakukan antara lain:

1) Membuat Rencana Pelaksanaan Pembelajaran (RPP) dengan materi Tematik Tema 3 Makanan Sehat.

2) Menyiapkan lembar observasi (pengamatan) sebagai pedoman atas proses pembelajaran menggunakan media audio visual.

3) Menyusun soal tes untuk menilai peningkatan hasil belajar siswa terhadap materi yang diajarkan.

b. Pelaksanaan Tindakan

Dilaksanakan tanggal 9 November 2020.

Deskripsi pelaksanaan tindakan pembelajaran adalah sebagai berikut :

Kegiatan pembelajaran sesuai dengan langka- langkah pembelajaran yang ada di RPP yang telah dibuat. Pembelajaran menggunakan plafform google meet.

Pada evaluasi siklus I diikuti oleh semua peserta didik kelas V, yakni sebanyak 17 peserta didik. Peserta didik diberi waktu 30 menit untuk mengerjakan soal evaluasi melalui google form yang linknya dikirim melalui WAG.

c. Observasi

Hasil observasi yang dilakukan oleh observer selama jalannya kegiatan pembelajaran dan mengamati hasil evaluasi pada akhir kegiatan siklus kedua bisa dikatakan cukup berhasil karena siswa yang tuntas sebanyak 11 siswa dari 17 siswa. Dengan kata lain siswa yang tuntas sudah mencapai 65\%. Namun, meskipun 
ketuntasan sudah mencapai $65 \%$ masih diperlukan perbaikan karena masih ada 6 siswa yang nilainya di bawah KKM.

\section{d. Refleksi}

Hasil belajar pada siklus II mengalami peningkatan dibandingkan dengan siklus I. Hasil evaluasi siklus I siswa yang tuntas mencapai $29 \%$, sedangkan pada hasil evaluasi siklus II siswa yang tuntas mencapai $65 \%$. Hal ini menunjukkan ada peningkatan hasil belajar siswa sebesar $36 \%$. Dari deskripsi di atas menunjukkan bahwa hasil rata-rata kelas meningkat pada siklus II, dengan kata lain dapat dikatakan cukup berhasil dalam pembelajaran sistem pencernaan makanan pada manusia karena siswa yang tuntas (KKM) sudah mencapai 65\%. Meskipun demikian, masih diperlukan perbaikan pembelajaran dengan media yang sama pada siklus III.

Berdasarkan hasil evaluasi siklus II tersebut, dapat dilihat presentase ketuntasan belajar siklus II sebagai berikut :

Tabel 2. Persentase Ketuntasan Belajar Siklus II

\begin{tabular}{ccccc}
\hline \multirow{2}{*}{ No Uraian } & \multicolumn{2}{c}{ Siswa yang Tuntas } & \multicolumn{2}{c}{ Siswa Belum Tuntas } \\
\cline { 2 - 5 } & Frekuensi & Persentase & Frekunsi & Persentase \\
\hline $\begin{array}{c}\text { 1Kondisi Awal (sesuai } \\
\text { dengan keadaan pada }\end{array}$ & 3 & $20 \%$ & 14 & $80 \%$ \\
$\begin{array}{l}\text { latar belakang) } \\
\text { 2Siklus I }\end{array}$ & 5 & $29 \%$ & 12 & $71 \%$ \\
3Siklus II & 11 & $65 \%$ & 6 & $35 \%$ \\
\hline
\end{tabular}

Tabel di atas dapat dijelaskan siswa yang belum tuntas belajar adalah sebagai berikut :

Pada kondisi awal sesuai dengan latar belakang penelitian, siswa yang belum tuntas sebanyak 14 siswa dari 17 siswa atau $80 \%$. $71 \%$.

Pada siklus I, siswa yang belum tuntas sebanyak 12 siswa dari 17 siswa atau

Pada siklus II, siswa yang elum tuntas sebanyak 6 siswa dari 17 siswa atau $35 \%$

Sedangkan siswa yang tuntas belajar adalah sebagai berikut :

Pada kondisi awal sesuai dengan latar belakang penelitian, siswa yang tuntas sebanyak 3 siswa dari 17 siswa atau $20 \%$.

Pada siklus 1, siswa yang tuntas sebanyak 5 siswa dari 17 siswa atau $29 \%$.

Pada siklus II, siswa yang tuntas sebanyak 11 siswa dari 17 siswa atau $65 \%$

Berdasarkan tabel diatas dapat dibuat diagram batang hasil belajar siklus II sebagai berikut : 

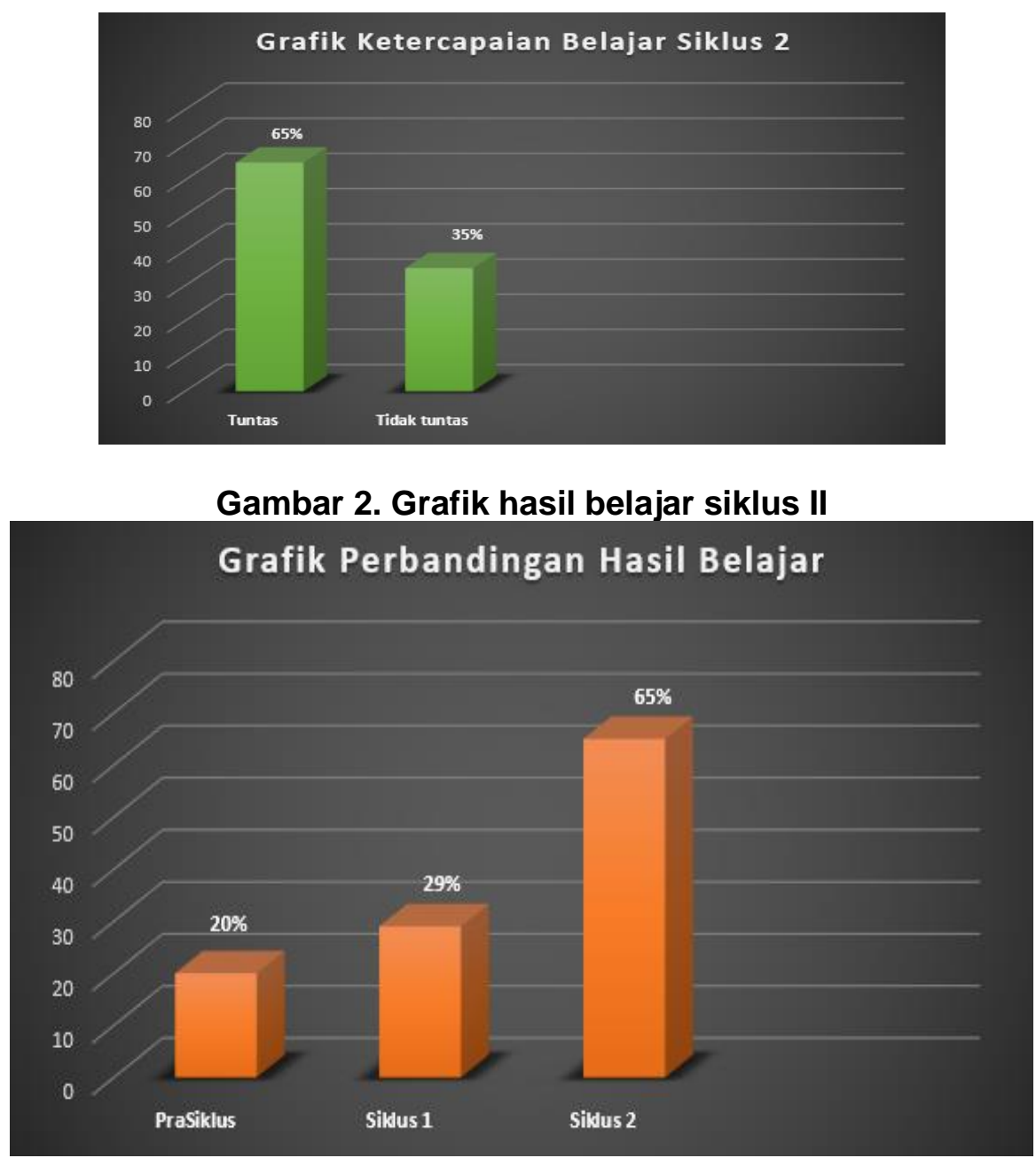

Gambar 3. Grafik perbandingan hasil belajar siklus I dan siklus II

\section{SIMPULAN}

Penggunaan media audio visual dapat meningkatkan pemahaman konsep materi sistem pencernaan makanan pada manusia Tema 3 Makanan Sehat kelas V SD Negeri Kedungmulyo, hal ini dibuktikan dari hasil belajar pada siklus I yaitu siswa yang belum tuntas sebanyak 12 siswa dari 17 siswa atau $71 \%$, sedangkan siswa yang tuntas sebanyak 5 siswa dari 17 siswa atau 29\%. Pada siklus II, Pada kondisi awal sesuai dengan latar belakang penelitian, siswa yang belum tuntas sebanyak 14 siswa dari 17 siswa atau $80 \%$. Pada siklus II, siswa yang belum tuntas sebanyak 6 siswa dari 17 siswa atau 35\%, sedangkan siswa yang tuntas sebanyak 11 siswa dari 17 siswa atau $65 \%$. Ini artinya hasil belajar siswa meningkat dari siklus I ke siklus II.

Implikasi serta rekomendasi, hendaknya guru mengembangkan pembelajaran menggunakan media audio visual pada pelajaran yang lain.

\section{DAFTAR PUSTAKA}

Achmadi, Abu dan Cholid Narbuko, 2010. Metode Penelitian. Jakarta: Bumi Aksara.

Arikunto, S. (2013). Prosedur Penelitian: Suatu Pendekatan Praktik. Jakarta: Rineka Cipta. 
Arikunto, Suhardjono, dan Supardi. 2015. Penelitian Pendidikan Kelas. Jakarta: Bumi Aksara

Alamul Huda. (2007). Panduan Praktis Microsoft Powerpoint 2007. Surabaya: PenerbitIndah

Ashar Arsyad. (2002). Media Pembelajaran. Jakarta : PT. Raja Grafindo Persada Hamalik. (2001). Kurikulum dan Pembelajaran. Jakarta: Bumi Aksara

Majid. (2004). Pembelajaran Tematik terpadu. Bandung: Remaja Rosda Karya. Oemar

Riski Ilham (2004). Belajar Sendiri Langsung Praktek Microsoft Powerpoint 2002.Surabaya: Indah

Triyanto. 2010. Mengembangkan Model Pembelajaran Tematik. Jakarta: Prestasi Pustaka.

Wardhani, I. (2019). Penelitian Tindakan Kelas. Tanggerang: Universitas Terbuka 